\title{
EFFECT OF TEMPERATURE, PHOTOPERIOD, BIOLOGICAL AND CHEMICAL FACTORS OF THREE HOST SPECIES ON THE PERFORMANCE OF THE EGG PARASITOID Trichogramma evanescens WEST. \\ Metwally, M. M.; M. W. El-Kordy; H. A. Mohamed;O. A. El-Sebai and A. A. Atta \\ Dept. of Plant Protection (Economic Entomology), Fac. of Agric., Cairo, Al-Azhar Univ.
}

\begin{abstract}
In order to evaluate the activity of Trichogramma evanescens west due to the effect of temperature, photoperiod egg size, weight, total protein, carbohydrates, and lipids of three host species Sitotroga cerealella Oliv., Pectinophora gossypiella, Spodoptera littoralis without scales and $S$. littoralis with scales. The highest percentage of parasitism was obtained in P. gossypiella $(66.75 \%)$ followed by 57.25 , 41.5 and $16.25 \%$ in $S$. cerealella, S. littoralis without scales and $S$. littoralis with scales, respectively. While, The highest percentage of adult wasps emerged from the parasitized host was occurred in $S$. cerealella (45\%). Results reflected eggs of $S$. cerealella was more preferred for $T$. evanescens wasps than $S$. littoralis eggs due to larger amount of protein, carbohydrates, lipids and egg weight (13.36, 2.4 and 3.59 $\mathrm{mg} / \mathrm{gm}$ ) respectively. The consequences of these observations led to high percentage of parasitism and adult wasps emergence (57.25 and $45.0 \%$ ) in case of wasps produced from $S$. cerealella. Host egg size significantly differed $(P=0.0098)$ between all tested host eggs. While, no significant difference $(P=0.0956)$ was recorded for the egg weight between all tested egg host. Effect of light period [light regimes; (A)16:8h $\mathrm{L}: D,(B) 12: 12 \mathrm{~h} \mathrm{~L}: D,(C) 8: 16 \mathrm{~h} \mathrm{L:D}$ at $25 \pm 1^{\circ} \mathrm{C}$ and $70 \pm 5 \% \mathrm{RH}$ ] on the rate of parasitism and sex ratio of the parasitoid $T$. evanescens. The highest rate of parasitism $(86.75$ $\%$ ) was recorded in the treatment $(A)$, while the lowest rate $(77.25 \%)$ was found in the treatment $(B)$. Sex ratios in the treatments (A, B and $C$ ) were $68.25,74.25$, and $78.5 \%$ for Females, respectively. No significant differences was recorded among different photoperiod regimes tested with respect to longevity and life cycle. Positive relationship between temperature and $T$. evanescens percentage of parasitism and negative relationship between longevity and temperature were recorded.
\end{abstract}

Keywords: Trichogramma evanescens, temperature, photoperiod.Host preferances.

\section{INTRODUCTION}

Trichogrammatidae are the most widely used natural bioagents in augmentation programmes (Ying Li, 1994). Trichogramma species are polyphagous egg parasitoids that attack lepidopterous hosts (Pintureau, 1990). Releases of Trichogramma are successfully used on large scale on corn, cotton, sugarcane, fruit tree and vegetable crops in more than 50 countries (Hassan, 1993; Ying Li,1994; Smith, 1996). Wasps of the Trichogramma genus have several advantages as biological control agents, including relative ease of rearing and fact that they kill their host in the egg stage before it causes feeding damage. Hassan (1982) and Bigler (1984)

Host selection process is usually based on Trichogramma biological characteristics, which includes fecundity, emergence rate, sex ratio, 
longevity, host preference for the target species, host searching activity and tolerance to local climatic conditions. According to Flanders (1937) and Gordh et al. (1999) successful parasitism is divided into five steps: host habitat location, host location, host acceptance, host suitability and host regulation. The first three steps are host selection can be affected by environmental conditions or by host factors such as host chemical or physical cues, shape, size and host age (Bourchier 1994).

Because parasitoid performance is related to host quality (Flanders, 1935 and Schmidt, 1994), and host species differ in various qualities (e.g., size, chorion thickness, and distribution) likely to be related to wasp fitness and efficacy.

There for objective of this study is to investigate the effect of temperature, photoperiod egg size, weight, total protein, carbohydrates, and lipids of three host species $S$. cerealella, $P$. gossypiella and $S$. littoralis on the performance and biological characteristics of $T$. evanescens such as percent of parasitism, percent of adult wasps emergence, life cycle and the sex ratio of progeny.

\section{MATERIALS AND METHODS}

\section{Mass rearing of the factitious host, S. cerealella.}

The eggs of grain moth, $S$. cerealella was used as a factitious host for the mass rearing of the egg parasitoid, $T$. evanescens. Wheat grains were first washed and then heated in water $(1 \mathrm{~kg} / 100 \mathrm{cc}$ water) in an oven for 2.5 hours at $250^{\circ} \mathrm{C}$. After 2 hours, grains were stirred. Referring to Wishert (1929) heating grains before use eliminates many problems (such as existence of mites and some stored product insects associated with the grains). Rearing of $S$. cerealella took place at $26^{\circ} \mathrm{C} \pm 1$ and $70-75 \%$ R.H. in a double-floor rearing cages made of aluminum and steel wire ( 80 meshes). The lower floor $(85 \times 71 \times 58 \mathrm{~cm})$ contained 15 trays and was fixed on a base with $123 \mathrm{~cm}$ height, while the upper floor $(85 \times 71 \times 58 \mathrm{~cm})$ was mobile and contained also 15 trays.

The trays $(68 \times 2 \times 49 \mathrm{~cm})$ were made of aluminum and steal wire that permit the moths to get out through their holes. The trays were filled by the heated wheat grains $(6 \mathrm{~kg} /$ tray). Eggs of Sitotroga were scattered on the wheat surface (6 g/tray) and then the trays were kept horizontally for 4-5 days (out of the cages) until egg hatching and ensuring the penetration of newly hatched larvae into the wheat grains. Then, the trays were placed vertically inside the cages until emergence of the Sitotroga moths. Emerged moths mostly dropped into plastic funnels, fixed to the cages under the trays, to polyethylene containers or jars. The containers were collected daily and the moths were poured inside cylinders, made of metal frame covered with fine wire (80 meshes). The cylinders containing moths were placed in ovipositional cages; each cage contained two parts, each of which carried 5 cylinders. Fine brushes (one over each cylinder) were used to dislodge the eggs from the cylinders' surfaces, when the cylinders manually or mechanically rotate inside the ovipositional cages, into a drawer beneath the 
cylinders. Fresh deposited eggs were collected daily from the drawer to be used for rearing of either the host or the parasitoid (Hassan, 1988 and Shoeb, 2005).

Mass rearing of the parasitoid, Trichogramma evanescens West.

Adult wasps of $T$. evanescens were obtained from department of biological control, Plant Protection Institute, Douki, Cairo, Egypt, reared on $S$. cerealella eggs. The parasitoid was reared at $26 \pm 1^{\circ} \mathrm{C}$ and $70-75 \% \mathrm{RH}$ in Department of Plant Protection, Faculty of Agriculture, Al-Azhar University. Fresh eggs of $S$. cerealella were glued on carton cards $(12.5 \times 8.5 \mathrm{~cm})$, each contained about $1 \mathrm{~g}$ of Sitotroga eggs (ca. 50.000 - 60,000 eggs). Cards were exposed to the parasitoid adults into transparent plastic jars, covered with black clothes and sealed with rubber band. Exposure rate was 3 cards of host eggs per 1 card of the parasitoid. After 24 hours, the host egg cards were collected from the jars and kept into new jar until the color of the eggs turned black (success of parasitization). Newly fresh Sitotroga egg cards were replaced in the jars for parasitization, the process was repeated every $24 \mathrm{~h}$ until more than $50 \%$ of the parasitoid adults died. The cards contained the black-colored (parasitized) eggs were kept under the same laboratory conditions until emergence of the parasitoid adults or they were stored in an incubator at $5^{\circ} \mathrm{C}$ till needed.

\section{Host preference of $T$. evanescens:}

Rearing of the egg parasitoid $T$. evanescens on eggs different hosts was conducted to evaluate the host preference of the parasitoid on each of the insect hosts separately. A 100 fresh eggs of each host (S. cearelella, $P$. gossypiella, $S$. littoralis With out Scales and $S$. littoralis With Scales) were exposed to twenty newly emerged $(0-24 \mathrm{~h}$ old $)$ and mated females of $T$. evanescens were confined in homeopathic vials under controlled condition at $26 \pm 1^{\circ} \mathrm{C}$ and $70-75 \%$ relative humidity $(\mathrm{RH})$ Eggs were checked daily to determine the tested biological parameters (\% parasitism, \% adult emergence, sex ratio of the emerged wasps and developmental period of $T$. evanescens), experiment was replicated four times at all tested host eggs.

\section{Effect of temperature on $T$. evanescens:}

Temperature regimes were used $\left(20,25\right.$ and $\left.30{ }^{\circ} \mathrm{C}\right)$ in three incubators. Twenty newly emerged $(0-24 \mathrm{~h}$ old $)$ and mated females of $T$. evanescens were confined in homeopathic vials. 100 fresh eggs of $S$. cerealella, were stuck on a strip of white paper $(0.5 \times 4 \mathrm{~cm})$ and assigned a number, treatment code and date. Wasps were provided individually with egg cards daily till they died. The whole set was maintained at required temperature treatment but all at $70 \pm 5 \% \mathrm{RH}$ and 14:10 L:D. Parasitized eggs were kept at the corresponding temperature and photoperiod regimes related to their treatments. After emergence, the number of female, male and unemerged progeny was recorded for all the temperature. Eggs were checked daily to determine the tested biological parameters (\% parasitism, \% adult emergence, sex ratio of the emerged wasps and developmental period of $T$. evanescens), Treatment was replicated four times at all tested temperatures. 


\section{Effect of photoperiod on T. evanescens :}

Photoperiod regimes were 12:12, $16: 8$ and 8:16 h L:D. in at $25 \pm 1^{\circ} \mathrm{C}$ and $70 \pm 5 \% \mathrm{RH}$. Number of females for each photoperiod treatment were prepared as explained in temperature experiment and exposed to fresh eggs of $S$. cerealella cards daily. Parasitized eggs were incubated in the same conditions. After 5 days, the parasitized eggs which turned black were counted and recorded. After emergence, female, male and unemerged progeny were noted down for all wasps in all treatments separately. Eggs were checked daily to determine the tested biological parameters (\% parasitism, \% adult emergence, sex ratio of the emerged wasps and developmental period of $T$. evanescens), Treatment was replicated four times at all tested photoperiods.

\section{Chemical analysis of host eggs:}

Chemical analysis of host eggs was carried out in the laboratory of Chemical analysis special unite, Plant Protection Institute, Agricultural Research Center (ARC) Douki, Cairo, Egypt,

\section{1- Chemicals:}

Bovine albumin standard was purchased from stanbio laboratory (Texas, USA). Commasie brilliant blue G-250 was from sigma (sigma Chemical co.) P-nitroanisole (purity 97\%) was obtained from Ubichem Ltd. (Ham pshire), while nicotinamide ademine dinucleotide phosphate (reduced from, NADPH) was from BDH Chemical Ltd. (Poole, England). The rest of Chemicals were of high quality and purchased from commercial local companies.

\section{2- Apparatus:}

Insects were homogenized for biochemical analysis in a chilled glass

Teflon tissue homogenizer (ST-2 Mechanic-Preczyina, Poland). After homogenation, supernatants were kept in a deep freezer at $-20^{\circ} \mathrm{C}$ till use for biochemical assays. Double beam ultraviolet /visible spectrophotometer (spectronic 1201, Melton Roy co., USA) was used to measure absorbance of colored substances or metabolic compounds.

3- Preparation of insects for analysis:-

Insects were homogenized in distilled water $(50 \mathrm{mg} / 1 \mathrm{ml})$. Homogenates were centrifuged at 8000 r.p.m. for $15 \mathrm{~min}$ at $5^{\circ} \mathrm{C}$ in a refrigerated centrifuge. The deposits were discarded and the supernatants were kept in a deep freezer till use.

Determination of total proteins:

Total proteins were determined by the method according to Bradford (1976).

\section{Determination of total carbohydrates:}

Total carbohydrates were estimated in acid extract of plant seedlings by the phenol-sulphuric acid reaction of Dubois et al.,(1956).Total carbohydrates were extracted from the plant and prepared for assay according to Crompton and Birt (1967) Determination of total lipids:

Total lipids were estimated by the method of Knight. et al (1972) 
Statistical analysis:.

Obtained data were subjected to statistical analysis by Analysis of variance (ANOVA) test and using a computer software SAS (SAS Institute, 2000). Means were determined and compared by Duncan multiple range test at $0.05 \%$ probability level (Duncan, 1955 ).

\section{RESULTS AND DISCUSSION}

\section{Host preference of $T$. evanescens:}

Rearing of $T$. evanescens on different egg hosts was tested to evaluate the host preference of the parasitoid on each of the insect hosts separately. Results in Table (1) Fig. (1) indicated percentage of parasitism significantly differed $(P=0.0006)$ between all tested host eggs. The highest percentage of parasitism was obtained in $P$. gossypiella $66.75 \%$ followed by $57.25,41.5$ and $16.25 \%$ for $S$. cerealella, S. littoralis without scales and $S$. littoralis with scales, respectively. P. gossypiella was preferred by $2.7 \%$ than S. cerealella and $30.8 \%$ than S. littoralis.

Results in Table (1) showed that the percentage of emerged wasps significantly differed $(P=0.0038)$ between all tested host eggs. The highest percentage of adult wasps emerged from the parasitized host was occurred in S. cerealella $45 \%$ followed by $36,6.0$ and $6.0 \%$ in P. gossypiella, $S$. littoralis without scales and $S$. littoralis with scales, respectively. The results cleared that the relationship between egg size, weight, total protein, carbohydrates, and lipids of the tested three host species $S$. cerealella, $P$. gossypiella, and $S$. littoralis on the performance and biological characteristics of $T$. evanescens.

All three nutrition resources protein, carbohydrates, and lipids are important to fulfil the various energetic requirements of the insect body but, so far as is known, only lipids are directly involved in egg production (Nijhout, 1994). From an adaptive point of view, lipids are a key physiological currency in parasitoids, as they appear to be the common resource underlying the trade-off between reproduction and survival (Ellers, 1996; Ellers and van Alphen, 1997). Therefore, results in Table (1) reflected that the host egg of $S$. cerealella was more preferred for $T$. evanescens wasps than $S$. littoralis egg due to it contain larger amount of protein, carbohydrates, and lipids 13.36, 2.4 and $3.59 \mathrm{mg} / \mathrm{gm}$ egg respectively compared to $11.73,1.23$ and 3.19 $\mathrm{mg} / \mathrm{gm}$ egg in S. littoralis. The consequences of these observations led to high percentage of parasitism and adult wasps emergence in case of wasps produced from S. cerealella 57.29 and $45.0 \%$, respectively compared to 41.5 and $6.0 \%$, respectively in S. littoralis (Table 2 ).

Protein is one of the main components of the egg yolk of insects (Nijhout, 1994) and parental nutritional experience has been shown to influence egg protein levels in some species (Rossiter et al., 1993). Size had a significant effect on the total protein concentration in the female ovaries. The lipid availability is largely responsible for the nutrition dependent relationship between size and fitness (Rivero and West 2002). 
Metwally, M. M. et al.

Also, results proved that there was a positive relationship between host egg size and weight with percentage of parasitism and emergence.

Host egg size significantly differed $(P=0.0098)$ between $S$. cerealella and tested host eggs. While no significant difference $(P=0.0956)$ was recorded for the egg weight between all tested egg hosts. Obtained results may play a part of interpretation and explanation of using the factious egg host of intensively for mass rearing and production of Trichogramma spp. around the world compared to the other factious hosts.

Accordingly, Flanders (1937); Gordh et al. (1999) and Vinson (1976), referred that successful parasitism is divided into 5 steps: host habitat location, host location, host acceptance, host suitability and host regulation. Host size had an obvious effect on choice of the first host in T. galloi Monje et al. (1999), while the probability of ovipositional probing after the antennal contact increases with increasing size of the host Reznik et al. (1992) . The shape and texture of the host is very important in host acceptance. It was found that odour played a key role while shape and texture have secondary effect on acceptance of a host Vinson (1976)

Consoli et al. (1999) found that the thickness of the exochorion might result in different drilling time by T.galloi and T. Pretiosum when drilling on eggs of the same chorion thickness. Additionally, the structural integrity of the chorion was an important factor limiting successful oviposition by T. Platneri in larger host eggs Mansfield, S. and N.J. Mills. ( 2004).

The rearing host species affects the size of the Trichogramma body obtained (Liu et al., 1994) including its ovipositor (Pak, 1988), and subsequent performance (Corrigan and Laing, 1994; Greenberg et al., 1998). Overall results revealed that the host egg of $P$. gossypiella and $S$. cerealella were preferred due to their achieved the highest percent of parasitism and emergence and containing large amount of protein, carbohydrates, and lipids while $S$. littoralis with scales was the least.

Table (1): Evaluation of $T$. evanescens performance on eggs of different insect hosts.

\begin{tabular}{|c|c|c|c|c|c|c|c|}
\hline host species & $\underset{\mu}{\text { Egg size }}$ & $\begin{array}{l}\text { Weight } \\
/ 100 \text { egg }\end{array}$ & $\begin{array}{l}\text { Protein } \\
\text { mg/gm } \\
\text { egg } \\
\text { weight } \\
\end{array}$ & $\begin{array}{c}\text { Carbohydrate } \\
\text { mg/gm egg } \\
\text { weight }\end{array}$ & \begin{tabular}{|l|} 
lipidsm \\
g/gm \\
egg \\
weight \\
\end{tabular} & $\begin{array}{c}\text { Emergence } \\
\%\end{array}$ & $\begin{array}{c}\text { Parasitis } \\
\mathrm{m} \%\end{array}$ \\
\hline S. cearelella & $\begin{array}{c}14.6 \\
\pm 0.19\end{array}$ & $\begin{array}{c}0.008 \\
\pm 0.0003\end{array}$ & $\begin{array}{c}13.36 \pm \\
0.74\end{array}$ & $2.4 \pm 0.82$ & $\begin{array}{c}3.59 \pm \\
0.66\end{array}$ & $45^{a}$ & $57.25^{a}$ \\
\hline P. gossypiella & $\begin{array}{c}18.39 \pm \\
0.66\end{array}$ & $\begin{array}{l}0.007 \pm \\
0.0003\end{array}$ & - & - & - & $36^{a}$ & $66.75^{a}$ \\
\hline \begin{tabular}{|c|} 
S. littoralis \\
with out scales
\end{tabular} & $\begin{array}{c}18.55 \pm \\
1.47 \\
\end{array}$ & $\begin{array}{c}0.006 \\
\pm 0.0004 \\
\end{array}$ & $\begin{array}{c}11.73 \pm \\
1.3\end{array}$ & $1.23 \pm 0.82$ & $\begin{array}{c}3.19 \pm \\
0.28 \\
\end{array}$ & $6^{b}$ & $41.5^{\mathrm{ab}}$ \\
\hline $\begin{array}{l}\text { S. littoralis } \\
\text { with scales }\end{array}$ & $\begin{array}{c}18.55 \pm \\
1.47\end{array}$ & $\begin{array}{c}0.006 \\
\pm 0.0004\end{array}$ & $\begin{array}{c}11.73 \pm \\
1.3\end{array}$ & $1.23 \pm 0.82$ & $\begin{array}{c}3.19 \pm \\
0.28\end{array}$ & $6^{b}$ & $16.25^{b}$ \\
\hline $\mathrm{R}$ value & 0.99018 & 0.90439 & & & & 0.96240 & 0.96240 \\
\hline $\mathrm{P}$ value & 0.0098 & 0.0956 & 0.1624 & 0.0008 & 0.0357 & 0.0038 & 0.0006 \\
\hline LSD & 1.513 & 0.0008426 & 2.561 & 0.351 & 0.0353 & 24.826 & 26.625 \\
\hline
\end{tabular}

Means in each columns with the same litter are not significantly differed at $5 \%$ 
Table (2): Evaluation of $T$. evanescens performance on eggs of different insect hosts.

\begin{tabular}{|c|c|c|c|c|c|}
\hline host species & $\%$ Parasitism & Emergence & $\begin{array}{c}\text { Longevity } \\
\text { (Days) }\end{array}$ & $\begin{array}{c}\text { sex ratio } \\
\% \text { o }\end{array}$ & $\begin{array}{c}\text { Life cycle } \\
\text { (Days) }\end{array}$ \\
\hline S. cerealella & $57.25^{\mathrm{al}}$ & $45^{\mathrm{a}}$ & 4.62 & $43.6^{\mathrm{D}}$ & $9^{\mathrm{b}}$ \\
\hline P. gossypiella & $66.75^{\mathrm{d}}$ & $36^{\mathrm{d}}$ & 4.5 & $39.85^{\mathrm{D}}$ & $8.3^{\mathrm{c}}$ \\
\hline $\begin{array}{c}\text { S. littoralis with } \\
\text { scales }\end{array}$ & $16.25^{\mathrm{C}}$ & $6^{\mathrm{D}}$ & 3.87 & $59.25^{\mathrm{d}}$ & $9.5^{\mathrm{du}}$ \\
\hline $\begin{array}{c}\text { S. littoralis } \\
\text { without scales }\end{array}$ & $41.5^{\mathrm{D}}$ & $6^{\mathrm{D}}$ & 3.75 & $46.4^{\mathrm{D}}$ & $9.75^{\mathrm{a}}$ \\
\hline P value & 0.0006 & 0.0038 & 0.709 & 0.0007 & 0.0029 \\
\hline LSD & 26.625 & 24.826 & 0.6252 & 9.7876 & 0.7015 \\
\hline
\end{tabular}

Means in each columns with the same litter are not significantly differed at $5 \%$

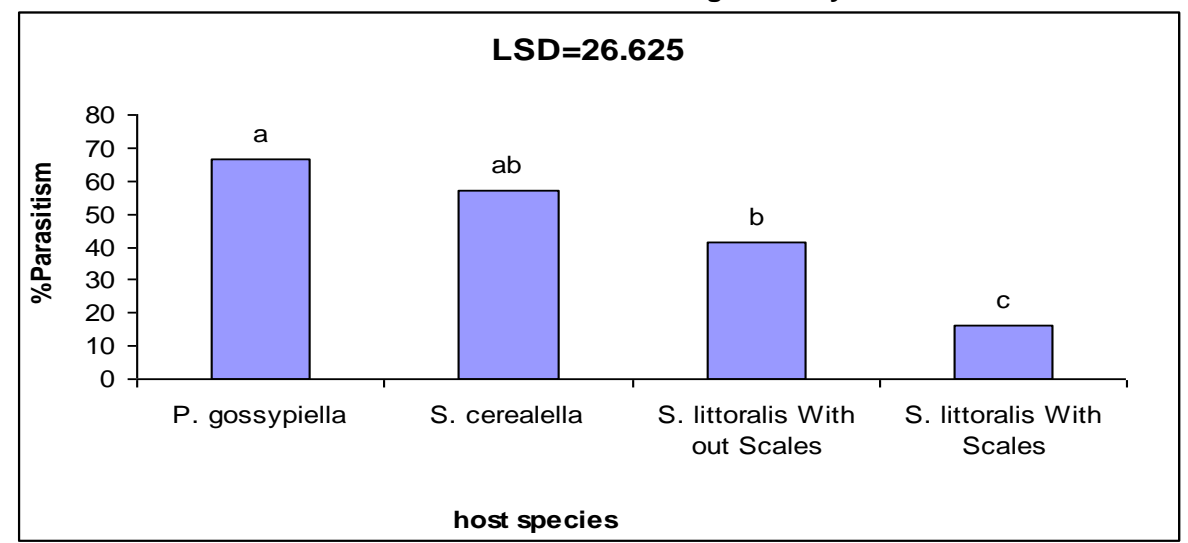

Fig. (1): Rearing of Trichogramma evanescens on different hosts eggs.

Sex ratio was biased in favor of females in the three laboratory hosts. number of females was greater than males, especially in case of $S$. littoralis, followed by $S$. cerealella, and then $P$. gossypiella, where the sex ratios (females) were 59.25, 46.4, 43.6 and 39.85 in $S$. littoralis with scales, $S$. littoralis with out scales $S$. cerealella, and $P$. gossypiella, respectively.

Effect of Photoperiod on T. evanescens :

Effect of Photoperiod on rate of parasitism and sex ratio of the parasitoid $T$. evanescens when exposed to fresh eggs of $S$. cerealella was estimated under different light regimes; (A)16:8h L:D, (B)12:12h L:D and (C) 8:16h L:D at $25 \pm 1^{\circ} \mathrm{C}, 70 \pm 5 \% \mathrm{RH}$. Results in table (3) and fig. (2) indicated that the percentage of parasitism significantly differed $(P=0.0001)$ between all tested photoperiods. Highest rate of parasitism (86.75\%) was recorded in the treatment $(A)$, while the lowest rate $(77.25 \%)$ was found in the treatment (B). The rate of parasitism in the treatments; (C) reached $85.5 \%$. Statistical analysis revealed that significant differences $(P=0.0001)$ of the sex ratio was recorded between all tested photoperiods. Sex ratios in the treatments $(A, B$ and C) were 68.25, 74.25, and 78.5\% Females, respectively (figure 1). Same trend was recorded for percentage of adult wasps emergence. There were no significant differences among different photoperiod regimes tested with respect to longevity and life cycle. 
Table (3): Effect of light regimes on rates of parasitism and sex ratio of Trichogramma evanescens under laboratory conditions.

\begin{tabular}{|c|c|c|c|c|c|}
\hline $\begin{array}{l}\text { Light } \\
\text { regimes }\end{array}$ & \%Parasitism & Emergence & $\begin{array}{c}\text { Longevity } \\
\text { (Days) }\end{array}$ & $\begin{array}{c}\text { sex ratio } \\
\% \text { ? }\end{array}$ & $\begin{array}{l}\text { Life cycle } \\
\text { (Days) }\end{array}$ \\
\hline $\begin{array}{c}16: 8 h \text { L: D } \\
(A)\end{array}$ & $86.75^{a}$ & $80.75^{d}$ & $3-5$ & $68.25^{c}$ & $9.25^{d}$ \\
\hline $\begin{array}{l}12: 12 \mathrm{~h} \mathrm{~L}: \mathrm{D} \\
\text { (B) }\end{array}$ & $77.25^{\circ}$ & $75.75^{\circ}$ & $3-6$ & $74.25^{\circ}$ & $9.25^{\mathrm{a}}$ \\
\hline $\begin{array}{l}\text { 8:16h L:D } \\
\text { (C) }\end{array}$ & $85.5^{\mathrm{a}}$ & $81.5^{\mathrm{a}}$ & $3-5$ & $78.5^{\mathrm{a}}$ & $9.5^{a}$ \\
\hline $\begin{array}{c}\mathrm{P}=0.5 \\
\mathrm{LSD} \text { Value }\end{array}$ & $\begin{array}{l}0.0001 \\
3.3932\end{array}$ & $\begin{array}{l}0.0001 \\
4.2068\end{array}$ & $\begin{array}{l}0.9186 \\
0.7886\end{array}$ & $\begin{array}{l}0.0001 \\
2.8465\end{array}$ & $\begin{array}{l}0.7479 \\
0.8431\end{array}$ \\
\hline
\end{tabular}

Means in each columns with the same litter are not significantly differed at $0.05 \%$

These results are in agreement with the findings of Tuncbilek and Ayvaz (2003) who reported that the adults lived in light regimes (L14: D10) and L6: D18) parasitized more eggs than total darkness. Also, potential fecundity of $T$. principium females (the number of mature ovarian eggs at emergence) and subsequent oogenesis (estimated by the number of mature ovarian eggs in non-ovipositing females) was independent of photoperiod. However, the percentage of females that oviposited was higher in the females, developed and kept under 6-12 $\mathrm{h}$ long photo phase than those developed and kept under ultra short (3L: 21D) and under long (18L: 6D and 21L: 3D) photo phases. The average duration of the pre-oviposition (egg retention) period showed opposite pattern to the photoperiodic response. A possible explanation of this reaction is that the delay in oviposition is adaptive, if the probability of finding a better host is high. Similar results obtained by Shirazi (2006) reported the effect of photoperiod (12:12, 14:10 and 16:8 h L: D) separately on T. chilonis. At 14:10 h L: $D$, fecundity (9.92 \pm 0.13 eggs / female/day) and adult emergence were significantly higher compared with 12:12 and 16:8 h L: D photoperiod regimes. There were no significant differences among different photoperiod regimes tested with respect to longevity, though it was higher at 16:8 $\mathrm{h} \mathrm{L}$ : D.

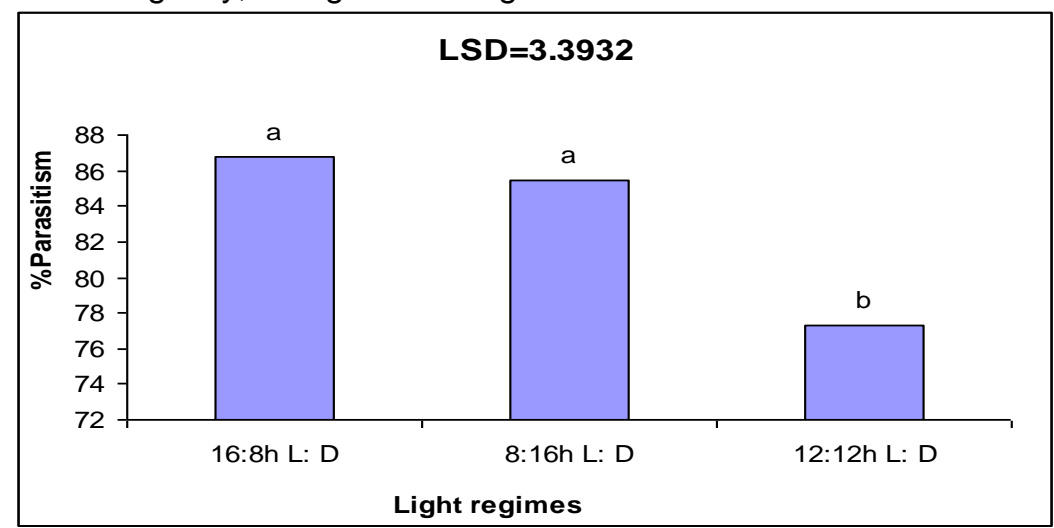

Fig. (2): Effect of light regimes on rates of parasitism of $T$. evanescens under laboratory conditions 


\section{Effect of temperature on T. evanescens:}

Effect of temperature on the biological aspects of the parasitoid $T$. evanescens when exposed to fresh eggs of $S$. cerealella was estimated under different constant temperatures 20,25 and $30^{\circ} \mathrm{C}$ and $70 \pm 5 \% \mathrm{RH}$. The results in Table (4) revealed that Positive relationship between temperature and percentage of parasitism, fecundity of $T$. evanescens significantly ( $P=$ 0.7065 ) increased with increase in temperature from $20-30^{\circ} \mathrm{C}$ (Fig 3 ). Female progeny also had a positive relationship with the temperature, as temperature increase percentage of emergence increased significantly $(P=0.683)$ from 20 to $30^{\circ} \mathrm{C}$. Negative relationship between longevity and temperature reached to the longest period $(7.75$ days $)$ at $20^{\circ} \mathrm{C}$. Life cycle significantly $(\mathrm{P}=0.0023)$ prolonged dramatically to 14.25 days at $20^{\circ} \mathrm{C}$ and shortend clearly to 8.2 days at $30^{\circ} \mathrm{C}$. From these results it is seems that $30^{\circ} \mathrm{C}$ appears to be the optimum temperature for rearing $T$. evanescens. the results were in agreement with Reznik et al. (2009) referred that the maximum cumulative percentage of parasitizing females, preemergence survival and lifetime fecundity were recorded at temperatures of $25-30^{\circ} \mathrm{C}$, which is close to the middle of this species temperature tolerance range. Accordingly, earlier study on Trichogramma principium Sug. et Sor. (Reznik \& Vaghina, 2006) suggest that the duration of the pre-oviposition period is shorter at high temperatures. It is well known that in synovigenic insects temperature may affect the duration of the pre-reproductive period by influencing the rate of oogenesis (Ratte, 1985; Brière et al., 1999). Harrison et al. (1985) reported that female of $T$. Pretiosum were slightly less abundant at lower and temperature. Similar results obtained by Maceda et al. (2003) recorded that as temperature increased, longevity of $T$. Pretiosum decreased accordingly also, female $T$. annulata lived significantly longer in $25^{\circ} \mathrm{C}$ than within the 20 $30^{\circ} \mathrm{C}$ range.

Table (4). Effect of temperatures on the biological aspects of $T$. evanescens under laboratory conditions.

\begin{tabular}{|c|c|c|c|c|c|}
\hline Temp. ${ }^{\circ} \mathbf{C}$ & \%Parasitism & Emergence & $\begin{array}{c}\text { Longevity } \\
\text { (Days) }\end{array}$ & $\begin{array}{c}\text { sex ratio } \\
\text { \% } \%\end{array}$ & $\begin{array}{c}\text { Life cycle } \\
\text { (Days) }\end{array}$ \\
\hline $20^{\circ} \mathrm{C}$ & $50.75^{\mathrm{C}}$ & $70.25^{\mathrm{C}}$ & $7.75^{\mathrm{a}}$ & $50.5^{\mathrm{C}}$ & $14.25^{\mathrm{a}}$ \\
\hline $25^{\circ} \mathrm{C}$ & $69.75^{\mathrm{D}}$ & $78.5^{\mathrm{D}}$ & $4.87^{\mathrm{D}}$ & $64.25^{\mathrm{D}}$ & $9^{\mathrm{D}}$ \\
\hline $30^{\circ} \mathrm{C}$ & $85.25^{\mathrm{a}}$ & $86.5^{\mathrm{a}}$ & $4.25^{\mathrm{D}}$ & $72.75^{\mathrm{a}}$ & $8.2^{\mathrm{D}}$ \\
\hline $\mathrm{P}=0.5$ & 0.7065 & 0.7686 & 0.9084 & 0.683 & 0.0023 \\
\hline LSD & 3.29 & 4.48 & 0.874 & 4.21 & 1.64 \\
\hline
\end{tabular}

Means in each columns with the same litter are not significantly differed at $0.05 \%$

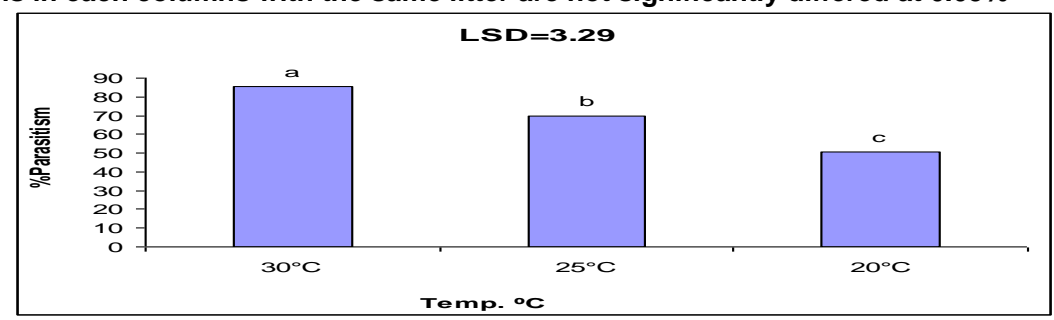

Fig.(3):Effect of temperatures on T. evanescens rates of parasitism under laboratory conditions. 


\section{REFERENCES}

Bigler, F., (1984) Mass production and field application of Trichogramma maidis Pintureau \& Voegele against the European corn borer in Switzerland. Abstract Vol. XVII. Intern. Cong. Ent. Hamburg, Germany, pp: 788.

Bourchier R. S., S. M. Smith, J. E. Corrigan and J. E. Laing (1994) Effect of host switching on performance of mass-reared Trichogramma minutum Biocontrol Science and Technology 4, 3, : 353-362

Bradford, M.M.(1976). A rapid and sensitive method for the quantitation of microgram quantities of proteins utilizing the principle of protein-dye binding. Anal. Biochem., 72:248-254.

Briere, J. F., P. Pracros , A. Y. le Roux, and J. S. Pierre (1999) A novel rate model of temperature-dependent development for arthropods. Environ. Entomol. 28: 22-29.

Consoli, F.L., E.W. Kitajima and J.R. Parra (1999) Ultrastructure of the natural and factitious host eggs of Trichogramma galloi Zucchi and Trichogramma pretiosum Riley (Hymenoptera: Trichogrammatidae). International Journal of Insect Morphology and Embryology, 28: 211 229.

Corrigan JE and JE. Laing (1994) Effects of the rearing host species and the host species attacked on performance by Trichogramma minutum Riley (Hymenoptera: Trichogrammatidae). Environmental Entomology 23, 755-760.

Crompton,M. and L.M. Birt (1967).changes in the amounts of carbohydrates. Phosphagen, and related compounds during the metamorphosis of the blowfly , Lucilia cuprina .J. Insect physiol.,13:1575-1595.

Dubios,M.; K.A. Gilles; Hamilton,J.K.; P.A. Rebersand F. smith (1956).

Colorimetric method for determination of sugars and related substances. Analyt. Chem.,28:350-356.

Duncan, D.B., (1955) Multiple range and multiple F-Test. Biometrics, 11: 124

Ellers, J. (1996) Fat and eggs: an alternative method to measure the trade-off between survival and reproduction in insect parasitoids. - Neth. J. Zool. 46: 227-235.

Ellers, J. and J. J. M. Van Alphen (1997) Life history evolution in Asobara tabida: plasticity in allocation of fat reserves to survival and reproduction. - J. Evol. Biol. 10: 771-785

Flanders, S. E. (1935) Host influence on the prolificacy and size of Trichogramma. Pan-Pacific Entomol. 11, 175-177.

Flanders, S.E., (1937) Habitat selection by Trichogramma. Ann. Entomol. Soc. Am. 30, 208-210. 
Gordh G. , Nurindah, and Bronwen W Cribb, (1999) Effects of physiological condition and experience on oviposition behaviour of Trichogramma australicum Girault (Hymenoptera: Trichogrammatidae) on eggs of Helicoverpa armigera Hübner (Lepidoptera: Noctuidae) Australian Journal of Entomology $38: 2,104-114$.

Greenberg S.M. , Donald A. Nordlund and Zhixin Wu. ( 1998) Influence of Rearing Host on Adult Size and Ovipositional Behavior of Mass Produced Female Trichogramma minutumRiley and Trichogramma pretiosum Riley (Hymenoptera: Trichogrammatidae) Biological_Control, 11 (1) 43-48

Harrison, W. W. , E. G. King and J. D. Quzts (1985) Development of Trichogramma exiguam and T. prwtiosum at five temperature regimes. Environ. Entomol. , 14: 118-121.

Hassan, S.A. (1988). Choice of the suitable Trichogramma species to control the European corn borer Ostrinia nubilalis $\mathrm{Hbn}$. and the cotton bollworm Helicoverpa armigera Hbn. Colloques de 1' INRA, No. 43, 197-198. In Trichogramma and other egg parasites.

Hassan, S.A., (1993) The mass rearing and utilization of Trichogramma to control lepidopterous pests: achievements and outlook. Pestic. Sci., 37(4): 387-391

Knight, J.A.; S. Anderson and J.M. Rawle (1972). Chemical basis of the sulfo-phospho-vanillin reaction for estimating total serum lipids. Clin. Chem., V.18: 199-202.

Liu, S.S., G.M. Zhang, Z.H. Shi \& F. Zhang (1994)The effect of the rearing host species and host age on the parasitization of the Asian corn borer, Ostrinia furnacalis, by Trichogramma dendrolimi. Les Colloques de I'INRA 73: 87-90

Maceda, A.; C. L. Hohmann, H. R. Santos (2003), Temperature effectes on Trichogramma pretiosum Riley and Trichogrammatoidea annulata De Santis. Brazilian Archives of Biology and Technology, 46, 27-32

Mansfield, S. and N.J. Mills (2004) A comparison of methodologies for the assessment of host preference of the gregarious egg parasitoid Trichogramma platneri. Biological Control, 29: 332-340.

Nijhout HF. (1994) Insect Hormones. Princeton, Princeton University Press.

Pak, G.A.; J.C. Lenteren, van (1988) Optimal host selection in the egg parasitoid Trichogramma. Colloques de I'INRA No 48:63-65 (Eds: Bouletreau, M.; Bonnot, G.) INRA Publications, France (ISBN 2-73800078-9)

Pintureau, B., (1990) Polymorphism, biogeographie etspécificité parasitaire des Trichogrammes européens (Hym. richogrammatidae). Bull. Soc. ent. Fr., 95: 17-38.

Ratte H.T. (1985) Temperature and insect development. In Hoffmann K.H. (ed.): Environmental Physiology and Biochemistry of Insects. Springer, Berlin, pp. 33-66. 
Reznik S.Ya. and N.P. Vaghina (2006)Heat shock influences on parasitization of the Angoumois grain moth Sitotroga cerealella Oliv. (Lepidoptera, Gelechiidae) eggs by the egg parasitoid Trichogramma principium Sug. et Sor. (Hymenoptera, Trichogrammatidae) females Entomological Review 86 (8), 861-865

Reznik S.Ya., N.D. Voinovich and S.G. Karpova (2009) Daily rhythms in parasitization of the Angoumois grain moth Sitotroga cerealella Oliv. (Lepidoptera, Gelechiidae) eggs by the egg parasitoid Trichogramma principium Sug. et Sor. (Hymenoptera, Trichogrammatidae) females Entomological Review 89 (1), 5-15

Rivero A. and S.A. West (2002) The physiological costs of being small in a parasitic wasp Evolutionary Ecology Research, , 4: 407-420

Rossiter, M.C., D.L. Coxfoster and M.A. Briggs (1993) Initiation of maternal effects in Lymantria dispar: genetic and ecological components of egg provisioning. J. Evol. Biol., 6: 577-589.

SAS Institute, (2000) SAS/STAT Users guide, version 8. SAS Institute. Cary, NC.

Schmidt JM (1994) Host recognition and acceptance by Trichogramma. Biological Control with Egg Parasitoids (ed. By E Wajnberg \& SA Hassan), pp. 165-199. CAB International, Oxon, UK.

Shirazi, J. (2006). Effect of temperature and photoperiod on the biological characters of Trichogramma chilonis Ishii (Hymenoptera: Trichogrammatidae) Pakistan Journal of biological Sciences 9(5): 820824.

Shoeb, Mona A. (2005). Bionomic parameters of the egg parasitoid species, Trichogramma evanescens West. ((Hym.: Trichgrammatidae) under laboratory conditions. Egypt. J. Biol. Pest Cont. 15(1\&2): p. 15-20.

Smith, S.M., (1996) Biological control with Trichogramma: advances, successes and potential for their use. Ann. Rev. Entomol., 41: 375406.

Tuncbilek, A. S. and A. Ayvaz (2003). Influence of host age, sex ratio, population density and photoperiod on parasitism by Trichogramma evanescens Westw. (Hymenoptera: Trichogrammatidae). Anzeiger fur Schadlingskunde, 76 (6): 176-180

Vinson, S.B. (1976) Host selection by insect parasitoids. Annual Review of Entomology, 21: 109- 133

Ying Li, (1994) Worldwide use of Trichogramma for biological control on different crops: A survey. In "Biological Control with Egg Parasitoids" (E. Wajnberg and S. A. Hassan, Eds.), pp. 37-53. CAB International, Berkshire, UK. 


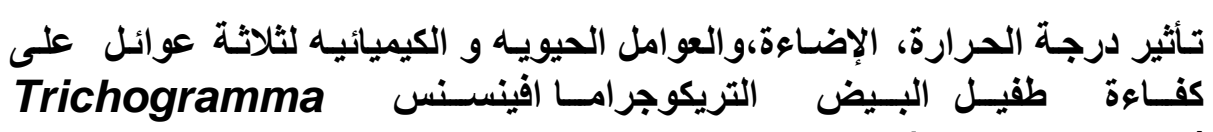

(evanescens)

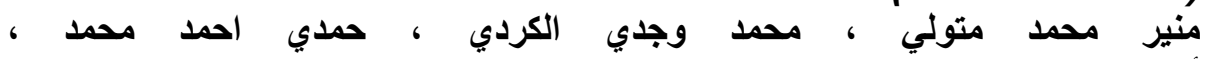

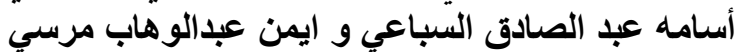
قسم وقاية النبات (حشرات اقتصادية) كلية الزراعه بالقاهره - جامعة الازهر

اجريت هذه الدراسه لمعرفة تأثير درجة الحرارة، الإضاءة، حجم البيض و وزئه ولهنه و التحليل

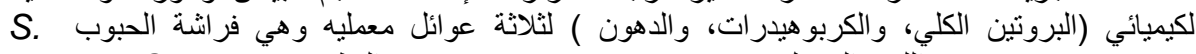
cerealella,

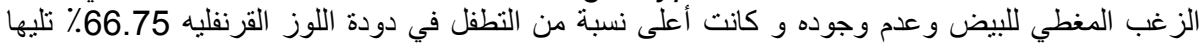

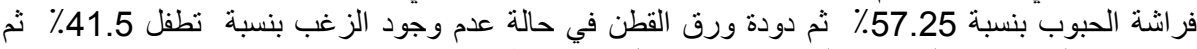

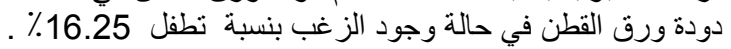

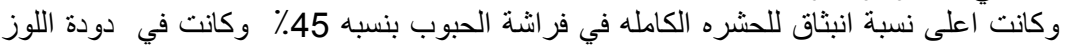

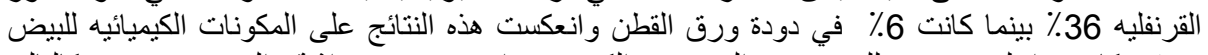

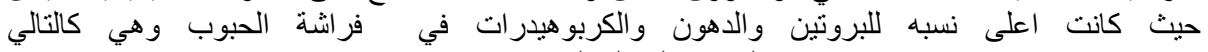

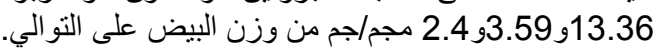

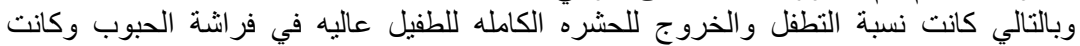

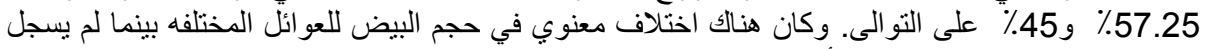

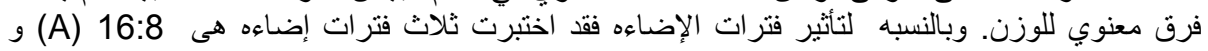

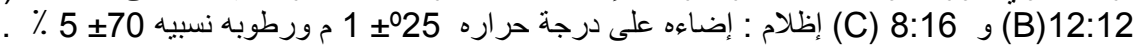

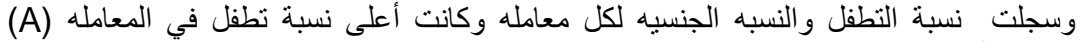

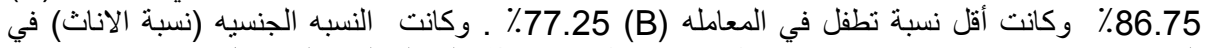

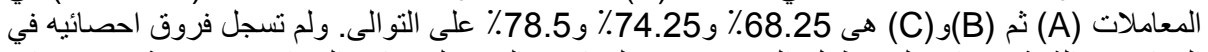

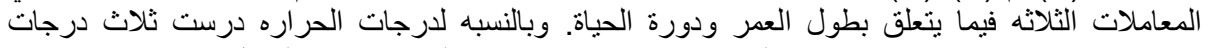

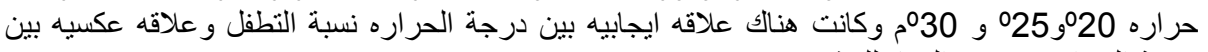
درجة الحراره ودورة الحياه للحشره.

كلية الزراعة - جامعة المنصورة كلية الزراعة - جامعة الأزهر

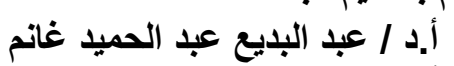
أ.د / محمد عبد الغفار احمد البد العمار 